\title{
The effect of calcium on gastric acid and gastrin secretion in antrectomized subjects
}

\author{
J. CHRISTIANSEN, J. F. REHFELD, AND F. STADIL \\ From the Departments of Surgical Gastroenterology F and Clinical Chemistry, Bispebjerg Hospital, \\ and the Department of Surgical Gastroenterology C, Rigshospitalet, Copenhagen, Denmark
}

SUMMARY Serum gastrin concentrations and gastric acid secretion were measured in nine antrectomized subjects during infusion of saline and calcium gluconate. The basal gastrin level was of the same magnitude as in normal individuals and unoperated duodenal ulcer patients. Calcium infusion only induced gastrin release in one patient and did not induce acid secretion in any of the patients.

The intravenous infusion of calcium stimulates gastric acid secretion in normal individuals (Reeder, Jackson, Ban, Clendinnen, Davidson, and Thompson, 1970) and in duodenal ulcer patients (Barreras and Donaldson, 1967). The mechanism by which calcium induces gastric secretion is unknown. Studies in patients with primary hyperparathyroidism have indicated that a release of gastrin may be the explanation (Trudeau and McGuigan, 1969; Christiansen and Aagaard, 1972; Dent, James, Wang, Deftos, Talamo, and Fischer, 1972), while a potentiation between gastrin and calcium probably does not occur in man (Christiansen and Hendel, 1972).

Studies by Reeder et al (1970) support the view that calcium exerts its effect on gastric acid secretion through the release of gastrin. Rosato, Mullen, Lanciault, Rosato, and Brooks (1973), who in conscious monkeys also found reproducible elevations in serum gastrin concentrations after calcium infusion, could not, however, demonstrate any correlation between serum gastrin concentration and gastric acid secretion.

Further information on any relationship between calcium concentration and gastrin stimulation of acid secretion could be found by studying the effect of an infusion of calcium salts on the gastric acid secretion in patients in whom the antral source of gastrin had been removed.

\section{Material and Methods}

Nine patients were studied, eight men and one woman, ages ranging from 22 to 60 years, who had had an antrectomy for duodenal or prepyloric ulcer

Received for publication 23 April 1974. at least three months before the examination was carried out. The patients all gave informed consent.

Five of the patients had a gastro-duodenostomy (Billroth I) and four a gastro-jejunostomy(BillrothII). The removed specimen measured at least $10 \mathrm{~cm}$ along the lesser curvature.

Four healthy male volunteers aged 22-25 acted as controls.

The patients and control subjects were examined after an overnight fast. A Levin tube was placed in the stomach under fluoroscopic control. Intermittent mechanical suction producing a subatmospheric pressure of $150 \mathrm{~mm}$ of mercury was used in the collection of the secretion. Through a thin polyvinyl tube welded to the Levin tube a marker substance was instilled into the stomach $\left({ }^{51} \mathrm{Cr}\right.$-EDTA, flow $30 \mathrm{ml} / \mathrm{hr}$ ) in order to determine recovery. The opening of the polyvinyl tube was $10 \mathrm{~cm}$ proximal to the most proximal opening of the Levin tube.

Saline was administered by constant intravenous infusion (flow $30 \mathrm{ml} / \mathrm{hr}$ ) for a control period of two hours.

Calcium gluconate was infused over the next two hours with a flow of $30 \mathrm{ml} / \mathrm{hr}$, delivering $4 \mathrm{mg}$ $\mathrm{Ca}^{++} / \mathrm{kg}-\mathrm{hr}$. The infusions were performed with a constant infusion pump.

The volume of the secretion collected was measured for each 15-minute period, and the concentration of $\mathrm{H}^{+}$and ${ }^{51} \mathrm{Cr}$-EDTA determined. The concentration of $\mathrm{H}^{+}$was determined by titration with an autotitrator (Radiometer, Copenhagen) to $\mathrm{pH} \mathrm{7.0.} \mathrm{The}$ concentration of ${ }^{51} \mathrm{Cr}$-EDTA was determined in a well counter. The volume of the secretion collected and the output of $\mathrm{H}^{+}$were corrected as to the actual recovery by way of the marker substance instilled. 
Repeated estimations of osmolarity by freezing point reduction were taken as an index of the degree of duodenal reflux.

Blood samples were taken from an indwelling catheter every 15 minutes. All samples were centrifuged immediately and serum for gastrin measurement was stored at $-20^{\circ} \mathrm{C}$. The concentrations of gastrin in serum were measured radioimmunochemically (Stadil and Rehfeld, 1971). The antiserum employed, 2604-8, was raised in rabbits against synthetic human gastrin (2-17) covalently coupled to bovine serum albumin (Rehfeld, Stadil, and Rubin, 1972). The antiserum binds four gastrin components of different molecular size, of which the largest, gastrin component I, appears unpaired (Rehfeld, Stadil, and Vikelsøe, 1974), while the remaining three-gastrin $-33,-17$, and -13 -each circulates in sulphated and nonsulphated pairs (for review see Rehfeld, 1973). Monoiodinated synthetic human gastrin (1-17) was used as tracer. The reliability parameters of the assay have been described in detail elsewhere (Stadil and Rehfeld, 1973). Blood samples for calcium determination were taken every

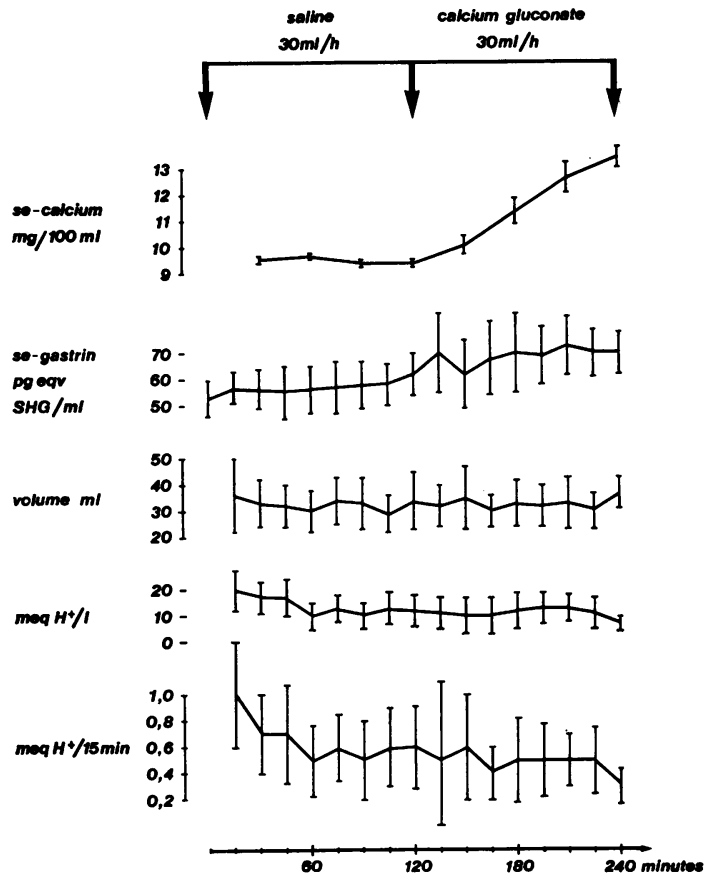

Fig 1 Serum calcium concentration $(\mathrm{mg} / 100 \mathrm{ml})$, serum gastrin concentration (pg equiv $\mathrm{SHG} / \mathrm{ml}$ ), volume secretion (ml/15 min), acidity (m-equiv $\left.\mathrm{H}^{+} / l\right)$, and acid output (m-equiv $\mathrm{H}^{+} / 15$ min) in nine antrectomized subjects during a control period of saline infusion, and during calcium infusion (means $\pm S E M$ )
30 minutes. Serum calcium concentration was determined by atomic absorption spectrophotometry.

For the statistical evaluation of the results Student's $t$ test for paired and unpaired data was applied (Snedecor and Cochran, 1967).

\section{Results}

Figure 1 shows the volume and acid secretion as well as serum calcium and serum gastrin concentration during the intravenous infusion of saline and calcium gluconate in the nine antrectomized subjects.

The serum calcium concentration rose significantly during calcium infusion (serum calcium concentration during saline infusion (mean \pm SEM): $9 \cdot 8 \pm 0 \cdot 1$ $\mathrm{mg} / 100 \mathrm{ml}$, and during calcium infusion: $12.0 \pm 0.4$ $\mathrm{mg} / 100 \mathrm{ml}, \mathrm{P}<0.001)$. The mean basal serum

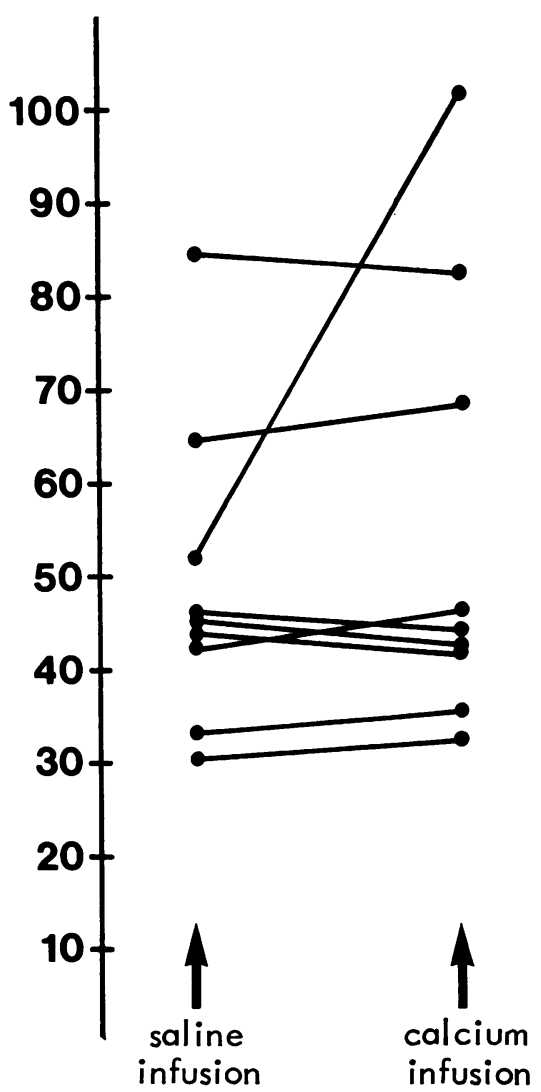

Fig 2 Serum gastrin concentration (pg equiv $S H G / m l$ ) during infusion of saline (0-120 min) and during infusion of calcium (120-240 min) in nine antrectomized subjects 
gastrin concentration was $48 \pm 4 \mathrm{pg}$ equiv/ml, and did not change significantly during saline infusion $(49 \pm 4 \mathrm{pg}$ equiv $/ \mathrm{ml}, \mathrm{P} \sim 0.50)$. During calcium infusion the mean serum gastrin concentration rose to $55 \pm 6 \mathrm{pg}$ equiv $/ \mathrm{ml}(\mathrm{P}>0.20)$ but analysing the data of the individual subjects shows that this rise could be ascribed to a rise in a single patient (fig 2).

The volume of secretion was unchanged (during saline infusion: $35 \pm 2 \mathrm{ml} / 15 \mathrm{~min}$, and during calcium infusion $34 \pm 4 \mathrm{ml} / 15 \mathrm{~min}, \mathrm{P}>0 \cdot 40$ ).

Acidity decreased slightly during calcium infusion (during saline infusion: $13 \pm 3$ mequiv $\mathrm{H}^{+} / 1$, and during calcium infusion $1 \pm 3$ mequiv $\mathrm{H}^{+} / 1, \mathrm{P}>$ $0 \cdot 10)$.

Acid output also decreased slightly during saline infusion (mean \pm SEM: $0.5 \pm 0.2 \mathrm{~m}$-equiv $/ 15 \mathrm{~min}$ ) and during calcium infusion: $0 \cdot 4 \pm 0.2$ m-equiv $\mathrm{H}^{+} / 15 \min (\mathrm{P}>0 \cdot 10)$.

The secretory responses during saline and calcium infusion were not influenced by duodenal reflux as no significant differences in the osmolarity of the gastric juice were found (see table).

The patient who exhibited a rise in serum gastrin concentration during calcium infusion showed the same pattern of volume and acid secretion as shown in figure 2. Mean serum gastrin concentration in the control subjects was $17 \pm 2 \mathrm{pg}$ equiv/ml during saline infusion and $29 \pm 3 \mathrm{pg}$ equiv/ml during calcium infusion $(P<0.05)$, ie, a mean percentage increase of 71 (range 48 to $88 \%$ ). Acid output rose from $0.8 \pm 0.1 \mathrm{~m}$-equiv $/ 15 \mathrm{~min}$ during saline infusion to $1 \cdot 2 \pm 0 \cdot 1 \mathrm{~m}$-equiv/15 min during calcium infusion $(50 \%$; $<<0.05)$.

\begin{tabular}{|c|c|c|c|c|c|}
\hline \multirow{2}{*}{$\begin{array}{l}\text { Patient } \\
\text { No. }\end{array}$} & \multicolumn{2}{|c|}{ Saline Infusion } & \multicolumn{2}{|c|}{ Calcium Infusion } & \multirow[t]{2}{*}{$\mathbf{P}$} \\
\hline & Mean & $S E M$ & Mean & $S E M$ & \\
\hline I & 236 & 4 & 240 & 3 & $>0.10$ \\
\hline II & 226 & 4 & 221 & 3 & $>0.10$ \\
\hline III & 212 & 4 & 212 & 3 & $>0.40$ \\
\hline IV & 218 & 1 & 226 & 4 & $>0.05$ \\
\hline v & 298 & 12 & 319 & 8 & $>0.10$ \\
\hline VI & 228 & 3 & 221 & 5 & $>0.10$ \\
\hline VII & 223 & 6 & 215 & 5 & $>0.20$ \\
\hline VIII & 251 & 4 & 268 & 6 & $>0 \cdot 10$ \\
\hline IX & 242 & 5 & 258 & 7 & $>0.10$ \\
\hline
\end{tabular}

Table Osmolarity (mosm/ $\mathrm{kg})$ of gastric aspirates during infusion of saline (0-120 min) and during infusion of calcium (120-240 min)

\section{Discussion}

The serum gatrin concentrations during infusion of saline in the antrectomized subjects was of approximately the same magnitude as reported earlier with the same radioimmunoassay technique in fasting normal subjects and unoperated duodenal ulcer patients (Stadil and Rehfeld, 1973). The low mean fasting gastrin concentration in the four controls in the present study is caused by very low values in one of the subjects. Similar findings have recently been reported by Stern and Walsh (1973), who in antrectomized patients with a gastro-duodenostomy found fasting and postprandial serum gastrin concentrations similar to those found in nonulcer and unoperated duodenal ulcer subjects. In antrectomized patients with a gastrojejunostomy the mean fasting and postprandial serum gastrin values were lower, but overlapping between the two groups occurred. In the present study the serum gastrin concentration in the four patients with a Billroth II anastomosis did not differ significantly from the group mean during saline infusion. The main source of this non-antral gastrin is probably the duodenum which in man is known to contain large amounts of immunoreactive gastrin.

Calcium infusion in subjects with an intact stomach results in a significant increase in serum gastrin concentration. In normal subjects Reeder et al (1970) found a $200 \%$ increase in serum gastrin concentration after calcium infusion and in duodenal ulcer patients a $135 \%$ increase. In patients with primary hyperparathyroidism Dent et al (1972) found an increase in serum gastrin concentration of 100 to $200 \%$ when serum calcium concentration rose $40-45 \%$, which compares with the increase in serum calcium concentration observed in the present study during the last hour of calcium infusion. In this study, all control subjects also showed an increase in serum gastrin concentration during calcium infusion, although to a lesser degree, than mentioned above. Of the nine antrectomized subjects, however, only one exhibited an increase in serum gastrin concentration after calcium infusion. The most likely explanation for this difference seems to be either that duodenal gastrin, unlike antral gastrin, is not released by calcium infusion or that the release of duodenal gastrin is less sensitive to calcium. The fact that one patient did show an increase in serum gastrin concentration after calcium infusion could be explained by retained antral tissue.

While calcium infusion in subjects with an intact stomach has resulted in an increase in acid output to 27 to $46 \%$ of the maximal Histalog-stimulated acid output (Barreras and Donaldson, 1967; Reeder et al, 1970), it did not in this study of antrectomized subjects result in any increase in either volume secretion, acidity, or acid output. This is in contrast to studies of Basso and Passaro (1970), who studied five patients who had had a truncal vagotomy and a 
distal gastrectomy. The induction of hypercalcaemia during four hours of calcium infusion produced a gradual rise in mean acid output with a maximum after two hours and falling thereafter. As a whole, the interpretation of their study is difficult, as no data are available on serum calcium concentration during calcium infusion, volume secretion, acidity, or serum gastrin concentration. Furthermore, as the patients were vagotomized the results are not directly comparable to those of the present study. The results also contrast with those of Smallwood (1967), who found that vagotomy inhibited the gastric hypersecretory effect of calcium administration.

The interpretation of the results of the present study must be that release of antral gastrin is a prerequisite of calcium to stimulate gastric acid secretion in man. This supports the conclusions of Reeder et al (1970), who found a roughly parallel increase in serum gastrin concentration and acid output during calcium infusion in patients with an intact stomach.

Other possible effects of calcium on gastric secretion include activation or release of cyclic-AMP, which may be the second messenger in gastrinstimulated gastric secretion (Sutherland, Hardman, Butcher, and Broadus, 1969; Sutherland and Robison, 1966), increased blood flow (Donegan and Spiro, 1960), or a local cholinergic effect or acetylcholine release (Murphy, Goldstein, Boyle, and Ward, 1966). In conclusion, the release of antral gastrin seems to be a necessary condition for calcium to induce gastric acid secretion in man. This does not, however, exclude other effects of calcium on the gastric secretory system.

The skilful technical assistance of Ninna Haack, Ulla Holst, and I. Paaske and her staff is gratefully acknowledged.

The study was supported by grants from P. Carl Petersen's Fond, the Danish Medical Research Council, Fonden for Storkøbenhavn, Faerøerne, og Grønland, and Christian X's Fond.

\section{References}

Barreras, R. F., and Donaldson, R. M., Jr. (1967). Effects of induced hypercalcemia on human gastric secretion. Gastroenterology, 52, 670-675.

Basso, N., and Passaro, E., Jr. (1970). Calcium stimulated gastric secretion in the Zollinger-Ellison syndrome. Arch. Surg., 101, 399-402.

Christiansen, J., and Aagaard, P. (1972). Parathyroid adenoma and gastric acid secretion. Scand. J. Gastroent., 7, 445-449.

Christiansen, J., and Hendel, L. (1972). Interaction of calcium and pentagastrin on gastric acid secretion in man. Gut, 13, 643-645.

Dent, R. I., James, J. H., Wang, C., Deftos, L. J., Talamo, R., and Fischer, J. E. (1972). Hyperparathyroidism: gastric acid secretion and gastrin. Ann. Surg., 176, 360-369.

Murphy, D. L., Goldstein, H., Boyle, J. D., and Ward, S. (1966). Hypercalcemia and gastric secretion in man. J. appl. Physiol., 21, 1607-1610.

Nilsson, G., Yalow, R. S., and Berson, S. A. (1973). Distribution of gastrin in the gastrointestinal tract of human, dog, cat, and hog. In Frontiers in Gastro-intestinal Hormone Research: Nobel Symposium XVI. Edited by S. Andersson, pp. 95-102. Almqvist and Wiksell, Stockholm.

Reeder, D. D., Jackson, B. M., Ban, J., Clendinnen, B. G., Davidson, W. D., and Thompson, J. C. (1970). Influence of hypercalcemia on gastric secretion and serum gastrin concentrations in man. Ann. Surg., 172, 540-546.

Rehfeld, J. F., Stadil, F., and Rubin, B. (1972). Production and evaluation of antibodies for the radioimmunoassay of gastrin. Scand. J. clin. Lab Invest., 30, 221-232.

Rehfeld, J. F. (1973). Gastrins in serum. Scand. J. Gastroent., 8, 577-583.

Rehfeld, J. F., Stadil, F., and Vikelsøe, J. (1974). Immunoreactive gastrin components in human serum. Gut, 15, 102-111.

Rosato, E. F., Mullen, J. L., Lanciault, G., Rosato, F. E., and Brooks, F. P. (1973). The dissociation of gastric acid output and plasma gastrin concentration after calcium infusions in conscious monkeys. Surgery, 73, 207-211.

Smallwood, R. A. (1967). Effect of intravenous calcium administration on gastric secretion of acid and pepsin in man. Gut, 8, 592-598.

Stadil, F., and Rehfeld, J. F. (1971). Radioimmunoassay of gastrin in human serum. Scand. J. Gastroent., Suppl., 9, 61-65.

Stadil, F., and Rehfeld, J. F. (1972). Preparation of ${ }^{125}$ I-labelled synthetic human gastrin I for radioimmuno-analysis. Scand. J. clin. Lab. Invest., 30, 361-368.

Stadil, F., and Rehfeld, J. F. (1973). Determination of gastrin in serum: an evaluation of the reliability of a radioimmunoassay. Scand. J. Gastroent., 8, 101-112.

Stern, D. H., and Walsh, J. H. (1973). Gastrin release in postoperative ulcer patients: evidence for release of duodenal gastrin. Gastroenterology, 64, 363-369.

Sutherland, E. W., Hardman, J. G., Butcher, R. W. and Broadus, A. E. (1969). The biological role of cyclic-AMP. (Some areas of contrast with cyclic-GMP). In Progress in Endocrinology (International Congress Ser., No. 184), edited by C. Gual, pp. 26-32. Excerpta Medica Foundation, Amsterdam.

Sutherland, E. W., and Robison, G. A. (1966). The role of cyclic- $3^{1}, 5^{1}$-AMP in response to catecholamines and other hormones. Pharmacol. Rev., 18, 145-161.

Trudeau, W. L., and McGuigan, J. E. (1969). Effects of calcium on serum gastrin levels in the Zollinger-Ellison syndrome. New Engl. J. Med., 281, 862-866. 